\title{
ON A COLLECTION OF TENTHREDINOIDEA FROM EASTERN CANADA.
}

\author{
By S. A. RoHwer,
}

Of the Bureau of Entomology, U. S. Department of Agriculture.

The following is a report of an interesting collection of Tenthredinoidea made mostly in the county of St. John, New Brunswick, by Mr. A. Gordon Leavitt, and sent to the U. S. National Museum. All the collection having been made in eastern Canada came from either the Canadian or Hudsonian Life Zone, and contains species found throughout these zones. Of the 22 genera all but 6 are Holarctic, and perhaps most of these occur in the Palæarctic, but have not yet been recognized by European workers.

Some of the generic names used in the following paper have not been used heretofore in connection with Nearctic species, and the conception of some of the genera is different from that usually held; but in all cases of inconsistency with the standard works an effort has been made to show that the present view is correct. All species referred to the following genera are believed to be congeneric with the type of each genus.

\section{Family TENTHREDINIDE. \\ Subfamily ARGIN A. \\ Genus ARGE Sehrank.}

ARGE BOREALIS (Kirby).

Female, Nerepis, New Brunswick, July 22.

This specimen is somewhat paler than the type, but the structure is as described in my notes from the type in the British Museum.

\section{ARGE MACLEAYI (Leach).}

Female, Nerepis, New Brunswick, July 24.

Under this name there seems to be a number of distinct forms, but this specimen is typical. 
Subfamily NEMATINAE.

Genus PTERONUS Jurine.

PTERONUS ANTENNATUS Marlatt.

Female, Nerepis, New Brunswick, August 19.

PTERONUS RUFOCINCTUS (Harrington).

Female, St. John, New Brunswick, June 14.

Only the three apical segments are black, and the insect is somewhat smaller, but is undoubtedly Harrington's species.

PTERONUS OCHREATUS, new species.

Belongs to the group of mendicus, but is distinct in the poorly defined ocellar basin, and characters in the saw.

Female.-Length, $5.5 \mathrm{~mm}$. Clypeus broadly, semicircularly emarginate; middle fovea small, nearly circular, and not very distinct; ocellar basin very poorly defined, better defined above; frontal crest broken by a very shallow depression; antennal foveæ large and extending a little above the crest; furrow above anterior ocellus extending beyond the ocellar line; the interocellar furrow wanting; third and fourth antennal joints equal; stigma rather narrow, gently rounded, apex sharply rounded; third cubital but little wider at the apex; lower discal cell of hind wings a little shorter than the upper; sheath robust at base, sharply pointed at apex; saw stout at base, tapering to an acute tip, with sharp teeth both above and below. Reddish-yellow; interocellar area, elongate spots on lateral lobes, metanotum, basal plates and most of tergum black. Wings slightly yellowish hyaline, vitreous; venation brown, costa and stigma, except base, yellowish. Basal two joints of antennæ and the third and fourth joints above brown, the rest of the antennæ the color of the body.

Type-locality.-St. John, New Brunswick. One female collected on July 14 by Mr. A. G. Leavitt.

Type.-Cat. No. 12922, U.S.N.M.

Genus PONTANIA O. Costa.

PONTANIA PUMILA, new species.

Belongs to Group II of Marlatt (Revision of Nematinæ of North Amer.ca) and is related to kincaidi Marlatt, but is smaller, the ocellar basin is wanting, and there are other differences.

Female.-Length $4 \mathrm{~mm}$. Clypeus broadly, shallowly, semicircularly emarginate; supraclypeal area convex; antennal foveæ angeled above; middle fovea rather shallow, elongate; ocellar basin wanting; interocellar furrow wanting; scutellar appendage dull, finely sculp- 
tured; stigma rounded on the lower margin, broader a little basad of middle; upper discal cell a very little longer than lower; sheath straight above, rounded at apex beneath; saw hyaline, with poorly defined teeth and transverse ridges. Black; mandibles (apices piceous), labrum, apex of clypeus, angles of pronotum broadly, tegulæ, legs below middle of coxæ, and venter of abdomen whitish or reddish-yellow. Wings hyaline; venation brown.

Male.-Very like the female, but the clypeus is more deeply emarginate. The hypopygidium is long and narrowed at the apex, which is rounded.

Type-locality.--St. John, New Brunswick. One female collected on July 14 by Mr. A. G. Leavitt. The male was collected by Mir. Leavitt, July 22, at Nerepis, New Brunswick.

Type.-Cat. No. 12920 , U.S.N.M.

PONTANIA LEAVITTI, new species.

Belongs to Group I of Marlatt ${ }^{a}$ and seems to be nearest to P. pallicomis (Norton), but differs in the structure of the sheath, clypeus, and dark orbits.

Female.-Length, $4.5 \mathrm{~mm}$. Clypeus deeply angularly emarginate, lobes sharply triangular; supraclypeal area strongly convex; middle fovea deep, rather large, circular; ocellar basin well defined, shining, hardly punctured; interocellar furrow well defined; head rather coarsely granular; third and fourth antennal joints subequal; anterior lobe of mesonotum rounded posteriorly, mesonotum dullish; scutellar appèndage shining, highly polished; stigma gently rounded on lower margin; sheath broad at base, tapering above and below to an acute awl-like tip, emarginate beneath; saw with small teeth above and below. Black; clypeus, labrum, mandibles (apices piceous) supraclypeal area, angles of pronotum, tegulæ, coxæ, trochanters and anterior legs pallid; posterior orbits, posterior legs, and venter reddish-yellow. Wings hyaline, iridescent; venation dark brown, basal half of stigma pallid.

Type-locality.-Nerepis, New Brunswick. One female collected July 11 by A. G. Leavitt.

Type.-Cat. No. 12921, U.S.N.M.

Named in honor of Mr. A. Gordon Leavitt, who collected the material referred to in this paper.

\section{Genus PRISTIPHORA Latrielle.}

PRISTIPHORA IDIOTIFORMIS, new species.

Female.-Length, $5 \mathrm{~mm}$. Very like idiota Norton, as determined by Marlatt, but differs as follows: Stigma and venation dark brown; abdominal segments 2 to 7 reddish-yellow; scutellar appendage shin-

${ }^{a}$ Rev. Nematinæ of North America, Tech. Series No. 3, U. S. Dept. Agr., 1896. 
ing, very finely sculptured, not distinctly granular; middle fovea more strongly defined but of the same type.

Male.-The male differs from the male of idiota in same characters as the female, but as in idiota has the abdomen black.

Type-locality.-Nerepis, New Brunswick. One female and two males, collected August 18 by Mr. A. G. Leavitt.

Paratype-locality.-Red Head, St. John, New Brunswick. One male collected September 1 by Mr. A. G. Leavitt.

Type.-Cat. No. 12923, U.S.N.M.

\section{PRISTIPHORA IDIOTA Norton.}

Male and female, Great Caribou Island, Labrador, July 27, 1906.

PRISTIPHORA DYARI Marlatt.

Female, Nerepis, New Brunswick, July 24.

This specimen differs from the type in having the upper part of the mesopleuræ and most of the anterior lobe of the mesonotum rufo-piceous. Structurally, however, it is the same.

PRISTIPHORA PALLICOXA, new species.

Related to $P$. banksi Marlatt, but has the legs and venter pale.

Female.-Length $5 \mathrm{~mm}$. Antennal foveæ rather small, extending to about the middle of eyes; middle fovea small and indistinct; walls of the ocellar basin wanting; postocellar area narrow, much wider than long, poorly defined on all sides; front coarsely, irregular granular, posterior orbits finely so; third antennal joint distinctly longer than fourth; mesonotum finely sculptured, shining; scutellum longitudinally carinate; scutellar appendage shining, very finely sculptured; first transverse cubitus wanting; stigma broadest at base, gently tapering to apex; upper discal cell longer than lower; sheath broad at base, slightly concave above, apex rounded to meet the broadened base; cerci robust. Black; mandibles (apices piceous), palpi, labrum, apex of clypeus, angles of pronotum broadly, tegulæ, venter, legs, except the apices of hind femora and tibiæ whitish. Wings hyaline, iridescent; venation dark brown, except the pallid costa.

Type-locality.-Nerepis, New Brunswick. One female collected July 22 by Mr. A. G. Leavitt.

$$
\text { Type-Cat. No. 12924, U.S.N.M. }
$$

\section{Genus CRYPTOCAMPUS Hartig.}

\section{CRYPTOCAMPUS PALLISTIGMUS, new species.}

Related to $C$. brachycarpæ Rohwer, but may be known by the rounded, not ridged, supraclypeal area, paler stigma, and more feebly tooth saw of the female. 
Female.-Length $5 \mathrm{~mm}$. Labrum strongly rounded at the apex; clypeus rather deeply semicircularly emarginate, lobes broadly triangular, rounded at the apex; supraclypeal area raised, rounded; middle fovea elongate, pointed toward the clypeus; antennal fover large, uniting with the supraclypeal foveæ; antennal furrow nearly complete, narrow; ocellar basin well defined, though the ridges are not sharp; interocellar furrow poorly defined; crest broken although not strongly so; third antennal joint very little longer than fourth; scutellar appendage irregularly punctured; cerci of median length, tapering apically; sheath straight above, rounded below; teeth of saw very small and weak; stigma slightly broader at base, sharply rounded at apex. Black; mandibles (apices piceous), most of clypeus, labrum, supraclypeal area, inner orbits to antennæ, posterior orbits to top of eyes (the orbits are dusky), legs (the tarsi dusky and femora brownish) reddish-yellow; extreme angles of pronotum and tegulæ pallid. Wings hyaline, iridescent; venation pale brown, stigma pallid.

Male.-Length $4 \mathrm{~mm}$. Differs from the female as follows: Third antennal joint slightly shorter than fourth, flagel pale beneath, and stigma dark brown. Hypopygidium pale and sharply pointed. The male is easily separated from brachycarpæx by the pointed hypopygidium.

Type-locality.-St. John, New Brunswick. Three females and two males collected July 18 by Mr. A. G. Leavitt.

Type.-Cat. No. 12921, U.S.N.M.

\section{Subfamily FHNUSIN E.}

Tribe FENUSINI.

Genus FENUSA Leach.

In 1817 Leach $^{a}$ described the genus Fenusa and named only Tenthredo (Emphytus) pumita Klug, which is therefore the type of the genus. In 1846 Tischbein ${ }^{b}$ in describing dohrnii referred it to a new genus Katiosyphinga. Dohrnii is therefore the type of Katiosyphinga, the genus originally being monobasic. Kaliosyphinga dohrnii Tischbein and Tenthredo (Emphytus) pumita Klug are congeneric, so the genera are the same. Fenusa is the older name.

Leach in the same paper ${ }^{c}$ described the genus Messa and named only Tenthredo (Emphytus) hortulana Klug, which is therefore the type of the genus. Konow ${ }^{d}$ does not include the genus Messa, but places its genotype in the genus Fenusa and the genotype of Fenusa in the genus Katiosyphinga. The genus Fenusa, as defined by Konow, ${ }^{e}$ is Messa Leach, and Kaliosyphinga as treated by Konow ${ }^{e}$ and from the original description, is Fenusa Leach.

a Zool. Misc., vol. 3, p. 126, n. 4.

$b$ Stettin Ent. Zeit., vol. 7, p. 79 .

c Zool. Misc., vol. 3, p. 126, n. 3, 1817. $d$ Gen. Insect., 1905, fas. 29.

$e$ Idem, p. 89. 
FENUSA DOHRNII (Tischbein).

Three females, Nerepis, New Brunswick, July 22, 24.

Tribe SCOLIONEURINI.

\section{Genus POLYBATES MacGillivray.}

POLYBATES SECUNDUS, new species.

Differs from $P$. slossonæ MacGillivray in the circular (not elongate) middle fovea, the wings are more dusky and the stigma is shorter and angled at the base.

Female.-Length, $3 \mathrm{~mm}$. Antennal foveæ large, sharply defined, not joining the small circular sharply defined lateral fovea; middle fovea small, circular, and well defined; supraclypeal area broadly rounded and spreading over the antennæ in low, rounded ridges; postocellar area broader at the occiput; interocellar furrow straight, ocellar line equal to the ocellocular line; flagellum punctured, hairy, the first joint a very little shorter than the second, the second and third equal; mesonotum with shallow, poorly defined punctures; legs and abdomen normal; saw of the same type as slosson but little more than twice as long as its greatest width, broader and somewhat angled at the base. Black; abdomen piceous; all of legs pale yellow; wings distinctly dusky, venation dark brown.

Type-locality.-Red Head, St. John, New Brunswick. Two females collected by Mr. A. G. Leavitt, September 1, 1907.

Type.-Cat. No. 12926, U.S.N.M.

\section{Genus PARABATES MacGillivray.}

PARABATES LEUCOSTOMUS, new species.

Easily known by the white clypeus, labrum, mandibles and tegulæ.

Female.-Length, $3 \mathrm{~mm}$. Area around the antennæ with small, irregular, poorly defined punctures; middle fovea rather large, circular and not sharply defined; antennal foveæ not sharply defined and not joining with the elongate lateral, frontal fovea; anterior ocellus at the apex of the flattened ocellar area; antennal furrows above the ocelli punctiform; interocellar furrow poorly defined; post ocellar line equal with the ocellocular line; third antennal joint about a third longer than the fourth, the fourth and fifth equal; stigma rounded on the lower margin, broadest in the middle; saw without strong teeth, the lower part with distinct ribs, upper part normal. Black; clypeus, labrum, basal half of mandibles, angles of pronotum and tegulæ white; legs below knees brownish white; wings dusky hyaline, iridescent; venation dark brown.

Type-locality.-St. John, New Brunswick. One female collected July 11, by Mr. A. G. Leavitt.

Type.-Cat. No. 12925, U.S.N.M. 


$$
\text { Subfamily SHI,ANDRIN AE. }
$$

Genus ANEUGMENUS Hartig.

Type.-Tenthredo (Emphytus) coronata Klug.

This genus may be separated from Selandria Leach by the absence of a cephal-caudad suture on the upper part of the mesoepisternum, and by the anal cell of the hind wings being longer than the median on the median nervure.

\section{ANEUGMENUS FLAVIPES (Norton).}

Six females, Nerepis, New Brunswick, July 18, 22; female, St. John's Bay, July 18.

\section{Genus STRONGYLOGASTER Dahlbom. STRONGYLOGASTER TACITUS (Say).}

Two males, Nerepis, New Brunswick, August 9, 22.

STRONGYLOGASTER SORICULATRIPES Cresson (not Provancher).

Female, Nerepis, New Brunswick, July 22.

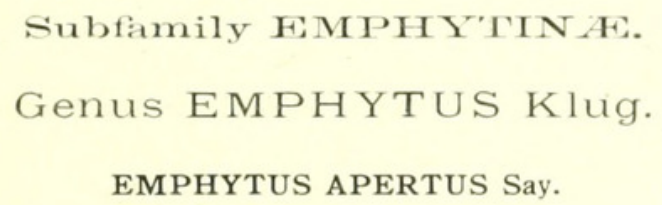

Female, Nerepis, New Brunswick, August 18.

\section{EMPHYTUS MELLIPES Norton.}

Two females, Nerepis, New Brunswick, August 18, 20.

$$
\text { Genus ERMILIA O." Costa. }
$$

$=$ Hypotaxomus Ashmead, Can. Ent., p. 311, 1898.

The type of Ermitia is Ermitia pulchella O. Costa which is conspecific with Tenthredo agrorum Fallén. In 1898 Ashmead $^{a}$ de- $^{-}$ scribed the genus Hypotaxonus and named as the type Strongylogaster pallipes Say. Tenthredo agroum Fallén and Strongylogaster pallipes Say are congeneric so Hypotaxonus Ashmead must be considered as a synonym of Ermitia O. Costa.

\section{ERMILIA PALLIPES (Say).}

Female, Nerepis, New Brunswick, July 22. 


\section{Genus APHILODYCTIUM Ashmead.}

=Parataxomus Mac Gillivray, Can. Ent., 1908, p. 367.

Strongylogaster rubripes Cresson and Taxonus multicolor Norton are congeneric so Parataxonus Mac Gillivray (1908) is a synonym of Aphilodyctium Ashmead (1898).

\section{APHILODYCTIUM MULTICOLOR (Norton).}

Four females, July 11, at St. John's Bay, New Brunswick; female, Nerepis, New Brunswick, July 22.

The first transverse cubitus is wanting in two of the specimens.

\section{Genus HEMITAXONUS Ashmead.}

HEMITAXONUS RUFOPECTUS, new species.

Readily distinguished from either of the American species by its entirely different color, and long slender antennæ.

Female.-Length, $7.5 \mathrm{~mm}$. Anterior margin of the clypeus gently, semicircularly emarginate, the lateral angles rounded; head below the crest and surface of the clypeus irregularly granular, the rest of the head and thorax shining, polished; ocellar basin nearly heart-shape, the anterior ocellus being in the smaller end; lateral frontal basins better defined than usual; post-ocellar area sharply defined all the way around; middle fovea elongate and nearly breaking through the crest; antennæ almost as long as the body, third joint slightly shorter than the fourth; legs and thorax normal; sheath rounded on the lower margin; third cubital cell slightly longer than the second, the transverse radius received near the apex. Black; clypeus, palpi, angles of the pronotum, tegulæ, basal fourth of the hind tibiæ, and a band on the hind basitarsis white; most of meso pleuræ, pectus, three basal abdominal segments (not basal plates) rufo-ferruginous; femora, four anterior tibiæ and tarsi except the paller color at the joints ferruginous; wings hyaline, iridescent; venation black.

Type-locality.-Nerepis, New Brunswick. One female collected August 22 by Mr. A. G. Leavitt.

Type.-Cat. No. 12928, U.S.N.M.

HEMITAXONUS ALBIDOPICTUS (Norton).

Male, Nerepis, New Brunswick, July 11.

Genus MONSOMA MacGillivray.

MONSOMA MAURA, new species.

Very like infernata (Norton), but the supraclypeal area is not sharply ridged, the female is colored like the male and the sculpture of the head is different.

Female.-Length $6 \mathrm{~mm}$. Anterior margin of the clypeus tridentate, the inner tooth smaller; head finely granular, the postocellar 
area shining, with distinct punctures; supraclypeal area rounded, but not carinated; antennal furrows distinct, not curving so strongly to the orbits as in infernata; furrow from the anterior ocellus distinct, extending both above and below; postocellar furrow not sharply defined; third antennal joint distinctly longer than the fourth, fourth and fifth subequal; dorsulum and scutellum shining, irregularly finely sculptured; scutellar appendage highly polished; first transverse eubitus wanting; sheath rather narrow, and sharply truncate at the apex. Black; most of the clypeus, labrum, angles of pronotum and tegulæ pallid; four anterior femora and tibæ beneath and base of posterior tibiæ dusky pallid; narrow apical margin of ventral segments pale. Wings dusky-hyaline, iridescent; venation dark brown.

Male.-Similar to the female; the clypeus is black and the apical margin almost truncate; the scutellar appendage is finely granular.

Type-locality._Nerepis, New Brunswick. One female collected July 18, by Mr. A. G. Leavitt. One male, which is described as the male, was collected July 14 at St. Johns Bay, New Brunswick, by Mr. A. G. Leavitt.

Type.-Cat. No. 12927, U.S.N.M.

Genus MACREMPHYTUS MacGillivray. MACREMPHYTUS TARSATUS (Say).

Female, St. John, New Brunswick, July 17.

\section{Genus DIMORPHOPTERYX Ashmead.}

\section{DIMORPHOPTERYX MELANOGNATHUS, new species.}

Readily separated from $D$. pinguis (Norton) by the black labrum, mandibles, antennæ and apex of abdomen.

Female.-Length $7 \mathrm{~mm}$. Emargination of the clypeus angular; front irregularly granular-punctate, behind the supraorbital line and posterior orbits are shining, with ill-defined punctures; antennal fovcæ large, extending above the middle of the eyes; ocellar basin well defined, but not sharply, joining with the middle fovea below; postocellar area convex; interocellar furrow wanting; first flagellar joint almost as long as second and third, the joints not so strongly constricted basally as in pinguis; mesonotum shining, with large punctures, the lateral lobes more sparsely so; pleuræ as in pinguis; sheath very stout, obliquely truncate at the apex. Black; four basal abdominal segments, basal half (or more) of the posterior femora and tibiæ rufo-ferruginous; four anterior legs and posterior tarsi reddishwhite. Wings iridescent, hyaline, slightly dusky; venation dark brown.

Type-locality.-Nerepis, New Brunswick. One female collected July 22, by Mr. A. G. Leavitt.

Type-Cat. No. 12929 , U.S.N.M. 


\section{Genus STRONGYLOGASTEROIDEA Ashmead.}

STRONGYLOGASTEROIDEA TERMINALIS (Say).

Female, Nerepis, New Brunswick, July 11.

$$
\text { Subfamily DOLFIRIN AE. }
$$

Genus DOLERUS Jurine.

DOLERUS APRILIS Norton.

Many males and females, Nerepis, New Brunswick, July 11, 22.

The tegulæ in two of the specimens are ferruginous. The sculpture of the scutellar appendage varies in this lot and it may be that there is more than one form, however, they are all apritis as understood by Norton.

\section{DOLERUS SIMILIS Norton.}

Nine females, July 22, 24.

In these specimens the color of the pronotum and the anterior lobe of the mesonotum is subject to variation. The pronotum in some is very dark and the anterior lobe of the mesonotum rufo-ferruginous, or the pronotum may be rufo-ferruginous and the anterior lobe of the mesonotum mostly dark brown.

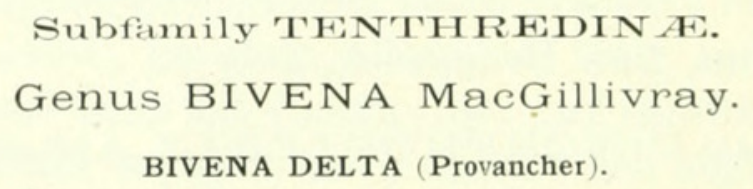

Female, Nerepis, New Brunswick, July 18.

\section{Genus PACHYPROTASIS Hartig.}

\section{PACHYPROTASIS OMEGA Norton.}

Female, St. John, New Brunswick, July 14; male, Nerepis, New Brunswick, July 18.

It has been suggested that this species is the same as the European rapæ Linnæus, but as there seem to be differences in the hypopygidium, therefore it seems best to keep them separate until a complete revision of the genus is possible. There is also a probability that there is more than one species under the name omega.

\section{Genus MACROPHYA Dahlbom. \\ MACROPHYA VARIA Norton.}

Two females, St. John, New Brunswick, June 14.

These differ from Norton's description in having the spot on the posterior coxæ white instead of rufous, and the basal plates are entirely black. 


\section{MACROPHYA TRISYLLABA Norton.}

Two females, St. John, New Brunswick, July 14; female Nerepis, New Brunswick, August 19.

Under the name trisyllaba there seems to be more than one species, and the above specimens are not typical, but until the type has been examined no satisfactory conclusion can be reached.

MACROPHYA FLAVICOX E Norton.

Eight females, St. John, New Brunswick, June 14 to July 22.

\section{Genus LABIDIA Provancher.}

LABIDIA ORIGINALIS (Norton).

Female, Cape Charles, Labrador, July 22.

$$
\text { Genus ALLANTUS Jurine. }
$$

ALLANTUS BASALARIS Say.

Ten females, Nerepis, New Brunswick, August 9-19; two females, St. John, New Brunswick, September 9.

\section{Genus TENTHREDO Linnæus. \\ TENTHREDO GRANDIS Norton.}

Female, Nerepis, New Brunswick, June 19.

\section{TENTHREDO SEMIRUBRA Norton.}

Male, Nerepis, New Brunswick, August 19.

This species was described from females collected in Massachusetts, but the above male can well be referred to this species. Specimens of the same species have been collected at Florissant, Colorado.

TENTHREDO LINEATA Provancher.

Two females, St. John, New Brunswick, July 18.

TENTHREDO MELLINA Norton.

Female, var. Nerepis, New Brunswick, August 18; male, var. Nerepis, New Brunswick, July 22.

The male has the pleuræ and pectus yellow.

TENTHREDO RUFOPECTUS Norton.

Female, St. John, New Brunswick, June 14; female, Nerepis, New Brunswick, August 18. 


\section{TENTHREDO RUFIPES Say.}

Three females, St. John, New Brunswick, July 14; three females, Nerepis, New Brunswick, July 22.

These represent a variety with the tegulæ and collar yellow.

\section{TENTHREDO DIVERSICEPS, new species.}

Very like Tenthredo titusi Rohwer and T. divergens Rohwer. The following characters separate it from divergens and many of them may be used in separating it from titusi: Markings white; posterior tibiæ black except basal half; pedicel twice as long as wide at apex; third antennal joint as in titusi; ocellar basin sharply defined and confluent with the middle fovea; hypopygidium obtusely pointed at apex, not broadly rounded.

Type-locality.-Nerepis, New Brunswick. One male collected July 22, by Mr. A. G. Leavitt. At St. John, Mr. Leavitt collected a male which is referred to this species with doubt.

Typé-Cat. No. 12930, U.S.N.M.

\section{TENTHREDO OBLIQUATUS MacGillivray.}

Seven males, Nerepis, New Brunswick, July 18.

TENTHREDO SEMICORNIS Harrington.

Male, St. John, New Brunswick, July 14.

TENTHREDO VERTICALIS Say.

Two females, Nerepis, New Brunswick, July 22.

\section{TENTHREDO ANGULIFERA Norton.}

Female, Nerepis, New Brunswick, July 22.

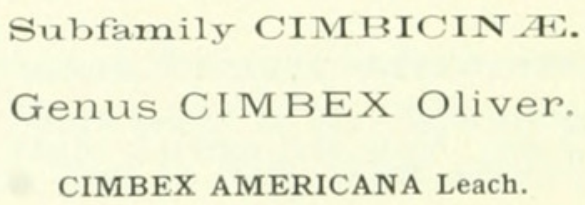

Typical form.--Two males, St. John, New Brunswick, July 11, 14.

Var. decemmaculatus Leach. Female, Nerepis, New Brunswick, August 9.

Family CEPHIDA.

Genus ADIRUS Konov.

ADIRUS TRIMACULATUS (Say).

Male, St. John, New Brunswick, July 14. 


\section{Family SIRECIDA.

Female, Nerepis, New Brunswick, August is.

In this specimen the antennæ are nineteen-jointed and the apical joints are somewhat compressed.

\section{SIREX FLAVICORNIS Fabricius.}

Female, Hopedale, Labrador, August 1, 1908.

\section{Genus PAURURUS Konow.}

PAURURUS CYANEUS (Fabricius).

Two females, St. John, New Brunswick, September 23 and October 3.

The specimen taken in October is noticeably smaller.

$$
\text { Proc.N.M.vol.38-10-14 }
$$




\section{$2 \mathrm{BHL}$ Biodiversity Heritage Library}

Rohwer, S. A. 1910. "On a collection of Tenthredinoidea from eastern Canada." Proceedings of the United States National Museum 38(1739), 197-209. https://doi.org/10.5479/si.00963801.1739.197.

View This Item Online: $\underline{\text { https://www.biodiversitylibrary.org/item/32576 }}$

DOI: https://doi.org/10.5479/si.00963801.1739.197

Permalink: https://www.biodiversitylibrary.org/partpdf/36081

\section{Holding Institution}

Smithsonian Libraries

\section{Sponsored by}

Smithsonian

\section{Copyright \& Reuse}

Copyright Status: NOT_IN_COPYRIGHT

This document was created from content at the Biodiversity Heritage Library, the world's largest open access digital library for biodiversity literature and archives. Visit BHL at https://www.biodiversitylibrary.org. 